\title{
PENGELOLAAN PEMBELAJARAN ALQUR'AN DI RA (STUDI KASUS PENGGUNA METODE QIRAATI)
}

\author{
Saifuddin \\ IAIN Syekh Nurjati Cirebon \\ E-mail: yusdoc_07@yahoo.co.id \\ Isnin Agustin Amalia \\ IAIN Syekh Nurjati Cirebon \\ E-mail:isninagustin63@gmail.com
}

Article received: 07 Maret 2018, Review process:11 Maret 2018

Article published: 30 Maret 2018

\begin{abstract}
Abstrak
Pendidikan menjadi pondasi yang paling penting dalam mencetak generasi yang handal, persaingan global saat ini menuntu setiap orang memiliki pengetahuan yang luas, tak terkecuali pengetahuan membaca Al Quran. Pembelajaran Al Quran harus ditanamkan semenjak dini, pembiasaan membaca Al Quran dengan terus menerus menjadikan kelancaran membaca Al Quran dengan baik dan benar. Metode yang tepat dalam pembelajaran Al Quran adalah dengan metode qiraati sebuah metode yang memudahkan anak-anak untuk belajar Al Quran. Pentingnya membaca agar Indonesia bangkit dari ketertinggalannya dengan Negara lain yang hanya memperoleh 51,7\% di bawah Filipina dan Thailand. Hal ini berkaitan dengan perencanaan, pelaksanaan dan evaluasi yang harus dikembangkan dalam pengelolaan pembelajaran Al Quran di RA Terutama ketika membaca Al Quran. Penelitian ini menggunakan penelitian kualitatif dengan pendekatan deskripsi analisis. Pendekatan ini dipilih karena penelitian ini berusaha memaparkan dan menafsirkan gambaran suatu kejadian yang memusatkan perhatian pada masalah-masalah aktual sebagaimana adanya pada waktu penelitian dilakukan. Dengan hasil penelitian, yaitu: (1) perencanaan dalam pembelajaran Al-Qur'an di RA diwujudkan dengan menyiapkan SDM Guru yang bersyahadah, kegiatan KBM yang berstandar Qiraati dan membangun lembaga RA yang kokoh dalam kelembagaannya, (2) pelaksanaan kegiatan belajar mengajar Al-Qur'an di RA diwujudkan dengan pembelajaran yang sesuai standar qiraati, pembinaan Guru melalui MMQ, hubungan kordinasi antar lembaga, korcam, dan korcab hingga korpus dalam pembelajaran, dan (3) evaluasi pembelajaran Al-Qur'an di RA dengan mengadakan kegiatan tes akhir santri, terbukti banyaknya santri yang mengikutinya dari sejumlah 27 lembaga diikuti peserta 390 orang dari jumlah santri seluruh lembaga berjumlah 1426 orang, hasil tersebut baru mencapai prosentase $27,35 \%$ di tahun 2017.
\end{abstract}

Kata Kunci: Pengelolaan, Pembelajaran dan Metode Qiraati 


\section{PENDAHULUAN}

Al Quran merupakan pedoman umat Islam di seluruh dunia maka mempelajarinya merupakan suatu kewajiban bagi setiap muslim. Mengenalkan Al Quran akan sangat baik jika disampaikan dari mulai kanak-kanak. Bahkan, ketika masih berada di dalam kandungan. Seorang anak yang sudah kenal dengan Al Quran maka akan menjadikan sebuah nilai dalam kehidupan seseorang yang berdasarkan nilai-nilai spiritual yang bersumber dari Al Quran. Al Quran mengandung nilai-nilai kehidupan yang seharusnya menjadi pelajaran utama bagi setiap muslim.

Al Quran adalah kitab suci umat Islam yang diwahyukan Allah kepada Nabi Muhammad Saw. Sebagai petunjuk dan pedoman hidup Al Quran perlu dibaca, dipelajari dan diperoleh maknanya untuk diamalkan. Persoalannya, pada umumnya Al Quran bersifat global, hanya dalam beberapa hal yang bersifat terperinci seperti dalam hal ibadah mahdahdan keluarga. Untuk mempelajari yang bersifat global tidak cukup hanya dengan mempelajari Al Quran dan terjemahnya, tapi mesti mempelajari ilmu-ilmu Al Quran dan tafsir Al Quran (Supiana, 2009:105).

Pemaparan yang disampaikan oleh Supiana menjelaskan bahwa Al Quran pastinya untuk dibaca. Logikanya bagaimana mungkin seseorang akan memahami Al Quran dengan baik dan benar kalau membacanya saja salah, maka untuk memahami kandungan secara benar tentunya $\mathrm{Al}$ Quran harus secara benar dalam membacanya. Hal ini memerlukan berbagai disiplin ilmu yang menunjang ilmu-ilmu Al Quran itu. Misalnya saja, dalam membaca kalimat ada alif yang harus dibaca ketika mengucapkannya, tetapi dalam redaksinya tidak ada harokatnya, maka memerlukan ilmu yang mendukungnya semisal ilmu shorof atau ilmu tajwid.Contohnya pada alif yang terdapat dalam surat Yasin, sebagai berikut:

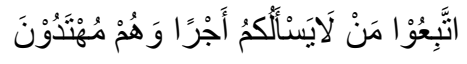

Alif pada lafad yang terdapat pada kalimat di atas menunjukkan bahwa alif tersebut tidak berharokat, namun ketika membacanya harus dibaca. Apakah alif tersebut dibaca fathah, atau kasroh, atau dhommah. Kalau membacanya salah maka makna yang terkandung di dalamnya akan berubah. Ketika didalami ternyata lafad tersebut adalah $f i$ 'il amar maka tentunya seseorang

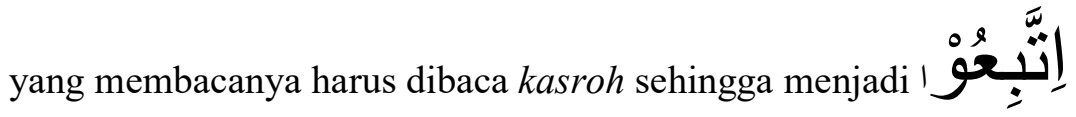


Hal ini menunjukkan bahwa hampir setiap orang salah membacanya karena sulitnya membaca Al Quran ketika salah membacanya maka tentunya akan berdampak pada berubahnya substansi yang terkandung di dalam Al Quran. Perlunya pengenalan Al Quran semenjak dini agar meminimalisir kesalahan. Banyak metode yang ditawarkan dalam setiap pengenalan $\mathrm{Al}$ Quran ini. Namun, yang paling ngetren terjadi di kalangan masyarakat ini adalah metode qiraati, sebuah metode yang memudahkan pemula untuk membaca Al Quran dengan baik dan benar. Metode ini hampir digunakan oleh setiap lembaga pendidikan tak terkecuali RA/TK yang menjadi lembaga terdepan dalam pengembangan dan pembelajaran Al Quran tingkat pemula.

Berbagai metode yang digunakan dalam pembelajaran Al Quran membawa dampak akan kemudahan setiap orang dalam mempelajarinya. Memang pada dasarnya seorang guru memberikan pengetahuan kepada peserta didiknya agar dapat menggunakan berbagai disiplin keilmuan terutam berkaitan dengan teori pembelajaran sebagai mana yang dikemukakan oleh Huda. Huda memberikan pandangan bahwa seorang guru harusnya menggunakan berbagai teori dalam mendukung pembelajaran.

Bank Dunia melaporkan tentang hasil pengukuran indikator mutu secara secara kuantitatif pada sekolah dasar (SD) di beberapa negara Asia. Hasilnya menunjukkan bahwa hasil tes membaca murid kelas IV SD, Indonesia berada pada tingkat terendah di Asia, berada di bawah Hong Kong 75,5\%, Singapura 74\%, Thailand 65,1\%, Filipina 52,6 \%, dan Indonesia 51,7\%. Dari hasil penelitian ini menunjukkan disebutkan pula bahwa para siswa di Indonesia hanya mampu menguasai 30\% dari materi bacaan yang dibacanya. Siswa Indonesia mengalami kesulitan menjawab soal-soal bentuk uraian yang memerlukan penalaran. Direktorat Pendidikan TK dan SD Departemen Pendidikan Nasional tahun 2000/2001 melaporkan bahwa rata-rata daya serap kurikulum secara nasional masih rendah, yaitu 5,1 untuk lima mata pelajaran (Majid, 2014:5).

Hasil studi internasional untuk reading and literacy (PIRLS) yang ditunjukkan untuk kelas IV SD juga menunjukkan hasil yang belum menggembirakan, dalam hal membaca, lebih dari 95\% peserta didik Indonesia di SD kelas IV juga hanya mampu mencapai level menengah, sementara lebih dari 50\% siswa taiwan mampu mencapai level tinggi dan advance. Hal ini juga menunjukkan bahwa apa yang diajarkan Indonesia berbeda dengan apa yang diujikan dan distandarkan pada tingkat internasional (Kemendikbud, 2013:77).

Penting untuk dicatat bahwa guru seharusnya membawa lebih dari satu teori pengajaran agar ia mampu memperoleh perspektif yang jelas mengenai keberagaman aspek dalam proses 
pembelajaran. Beberapa paradigma teoritis terkadang berusaha untuk menjelaskan fenomena pengajaran dan pembelajaran selengkap mungkin, tetapi dalam praktiknya guru akan menghadapi realitas yang sama sekali berbeda (Huda, 2015:36).

Hal ini memberikan sebuah gambaran bahwa seorang guru harus menerapkan model pembelajaran yang sesuai bagi peserta didiknya. Penelitian ini berupaya untuk menggali pembelajaran Al Quran yang tepat dan benar dalam membacanya terutama bagi anak-anak yang baru mengenal Al Quran. Metode qiraatiyang akan diteliti dalam penelitian ini, karena banyak kelebihan yang mempermudah bagi peserta didik dalam mempelajarinya. Cirebon sebagai kota wali yang sudah seharusnya menjadikan Al Quran sebagai bekal dalam kehidupannya, tentunya mau tidak mau harus mempelajari Al Quran semenjak dini. Sangat kontras jika warga Cirebon yang memeluk Islam tidak bisa membaca Al Quran dengan baik dan benar.

Perkembangan ilmu pengetahuan dan teknologi menuntut setiap guru untuk melakukan inovasi-inovasi yang dapat mempertahankan nilai-nilai pembelajaran yang dapat mengantarkan peserta didik untuk memiliki nilai-nilai dan meraih prestasi yang diharapkan oleh semua pihak. Pertumbuhan penduduk menuntut pendidik siap menjadi tenaga handal yang menerima setiap generasi yang berkeinginan untuk belajar dan menerima proses pembelajaran yang diterima oleh peserta didik. Globalisasi kehidupan menuntut untuk siap menghadapi setiap perubahan yang hampir terjadi setiap menit, banyak anak-anak yang terjebak oleh arus globalisasi tersebut. Tantangan yang dihadapi oleh pendidik, menuntut dengan berbagai model, strategi dan pendekatan yang merupakan upaya untuk pengembangan potensi yang dimiliki oleh pendidik dalam menciptakan inovasi baru.

Pengamatan yang kami lakukan dengan studi dokumen yang berupa (visi, misi dan tujuan sekolah), sebagai bahan pembanding antara perilaku orang yang ada di dalam sekolah dengan visi, misi dan tujuan sekolah tersebut, hasil prestasi siswa dengan perilaku siswa yang mungkin bisa diamati dalam kesehariannya di sekolah, kebiasaan yang berlangsung lama yang dilakukan. Penelitian ini akan berlanjut pada tingkat kepribadian setiap guru dan kepala sekolah melalui studi pengamatan lapangan. Cara mengajar guru dan perolehan jam mengaja guru.

Pengamatan penelitian juga akan dicatat setiap hasil wawancara dan kejadian penting yang berkaitan dengan penelitian, jika dalam wawancara akan direkam dalam alat perekam atau dengan dokumentasi photo yang bisa memberikan penjelasan secara visual tentang pengamatan penelitian yang dilakukan, catatan bisa dari sumber-sumber yang mendukungnya bukan hanya 
wawancara atau kejadian penting, bahkan kejadian yang kurang penting tapi ada kaitannya dengan penelitian akan dicatat dalam penelitian ini.

Dari latar belakang masalah peneliti membuat rumusan masalah bahwa metode qiraati menjadi pilihan lembaga pendidikan terutama RA yang ada di Kabupaten Cirebon dalam mengenalkan kepada peserta didik tentang membaca Al Quran dengan baik dan benar, dengan melihat aspek yang akan dikembangkan dari mulai perencanaan metode ini digunakan, melaksanakan metode ini, dan mengevaluasi metode ini.

\section{METODOLOGI}

Penelitian ini menggunakan penelitian kualitatif dengan pendekatan deskripsi analisis. Pendekatan ini dipilih karena penelitian ini berusaha memaparkan dan menafsirkan gambaran suatu kejadian yang memusatkan perhatian pada masalah-masalah aktual sebagaimana adanya pada waktu penelitian dilakukan. Pendekatan ini peneliti menggunakan pembahasan yang berkaitan dengan $5 \mathrm{w}$ dan $1 \mathrm{~h}$ (apa, kenapa, kapan, siapa, dimana dan bagaimana), dalam penelitian ini data yang dikumpulkan berdasarkan interview guide (petunjuk wawancara) dan dokumen yang ada kaitannya dengan penelitian ini, penelitian ini hanya memberikan gambaran yang terjadi dalam lapangan penelitian, namun dengan tidak menguji hipotesisnya.Penelitian bersifat alamiah tanpa adanya unsur lain yang harus dipaksakan untuk mendapatkan penelitian yang sempurna, penelitian ini hanya meneliti kemampuan siswa membaca Al Quran dengan metode qiraati baik pada aspek perencana, pelaksana dari evaluasi pembelajaran. Subjek penelitian ini, tentunya berkaitan dengan kepala sekolah, guru, murid dan Kementerian Agama Kabupaten Cirebon yang menjadi informan dalam penelitian ini.

Instrumen yang digunakan dalam penelitian untuk pengumpulan data ini adalah: (1) petunjuk wawancara, (2) rekaman suara, (3) rekaman gambar, (4) dokumen-dokumen sekolah , (5) catatan lapangan yang tertulis dalam buku, dan 7) lembar observasi penelitian.

\section{HASIL PENELITIAN}

a. Perencanaan pembelajaran metode qiraati dalam pembelajaran di RA Kabupaten Cirebon Perencanaan yang utama dalam metode Qiraati adalah mempersiapkan calon guru, hal ini karena dalam Qiraati menganut prinsip tidak ada anak yang bodoh, dalam penegertian semua anak bisa mengikuti pembelajaran Al-Qur'an jika mengikuti tata cara dan metode yang diajarkan Qiraati, sehingga persoalan terbesar justru pada diri kompetensi guru ketika menyampaikan pelajaran. 
PPL dilaksanakan kurang lebih satu bulan dengan tugas pokok mempraktekkan teori-teori yang diajarkan dalam metodologi dalam sebuah pembelajaran, sehingga calon guru menghayati dan merasakan secara langsung bagaimana mengajar Al-Qur'an dengan metode Qiraati. Hal-hal yang dilakukan dalam PPL sejatinya meneguhkan tekad dan niat menjadi guru Al-Qur'an dengan segala konsukensi dan tanggungjawabnya.

b. Pelaksanan pembelajaran metode qiraati dalam pembelajaran di RA Kabupaten Cirebon

Pembelajaran Al-Qur'an metode Qiraati berlangsung satu jam dengan tambahan persiapan pra pelajaran selama 15 menit untuk drill doa-doa harian, hafalan surat-surat pendek dan bacaan shalat.Dalam satu jam pembelajaran terbagi menjadi 3 sesi, yaitu sesi pertama 15 menit klasikal membaca peraga secara bersama-sama sesuai jilid; sesi kedua, selama 30 menit secara individual berupa munaqasah per-santri sesuai dengan halaman jilid yang telah diperoleh santri; sesi ketiga, selama 15 menit klasikal berupa membaca peraga bersama-sama dengan cara terbalik dari peraga yang pertama.Di tengah pembelajaran agar tetap kondusif maka santri ditugaskan latihan menulis huruf Al-Qur'an dengan meniru dan menulis ulang materi sesuai jilidnya.

c. Evaluasi pembelajaran metode qiraati dalam pembelajaran di RA Kabupaten Cirebon

Evaluasi dalam pembelajaran Qiraati berbasis kompetensi yang dicapai santri, artinya jika seorang santri telah memenuhi target halaman dari jilid yang sedang ditekuninya dan mampu membaca dengan mujawwad dan tartil, maka berhak diuji oleh kepala sekolah.Mekanisme pengujian dimulai dengan pengecekan buku prestasi santri yang memuat informasi tentang presensi harian santri dan jilid yang dibaca, proses pengujian dilakukan setelah kegiatan pembelajaran usai dan diantar oleh guru pada jilid yang bersangkutan. Hal ini dimaksudkan untuk dapat mengetahui hasil evaluasi secara langsung dari kepala sekolah kepada guru pengampu yang bersangkutan, jika santri yang diuji kurang cakap membaca dengan indikator kurang lancar, maka akan dikembalikan kepada kelas tersebut untuk dievaluasi ulang.

\section{PEMBAHASAN}

a. Perencanaan pembelajaran metode qiraati dalam pembelajaran di RA Kabupaten Cirebon.

Perencanaan ini merupakan langkah pertama yang sangat penting bagi suatu kegiatan, tanpa perencanaan suatu kegiatan menjadi amburadul dan tidak terarah. Bahkan, keberhasilkan suatu kegiatan ini tergantung bagaimana perencanaan itu dibuat. Termasuk bagaimana program qiraati ini berjalan. Tentunya menggunakan perencanaan yang menjadi prosedur kegiatan qiraati. 
Dibuatnya perencanaan ini menjadikan qiraati sebagai lembaga yang kuat dan kokoh sampai sekarang.

Diskusi peneliti dengan kepala sekolah menunjukkan bahwa pembangunan sumber daya manusia menjadi skala prioritas bagi kepala sekolah mempersiapkan guru-guru dengan mengikuti pelatihan-pelatihan pembelajaran bahkan mengikuti pembelajaran qiraati dari awal sampai memperoleh syahadah. Ini menunjukkan bahwa perencanaan program qiraati sangat serius. Terbukti dengan banyaknya guru-guru yang mengajar hampir 100\% memperoleh syahadah.

b. Pelaksanan pembelajaran metode qiraati dalam pembelajaran di RA Kabupaten Cirebon.

Hasil wawancara ini sebagai bukti bahwa ada keberhasilan yang meningkat dari setiap pembelajaran yang dilakukan oleh setiap guru. Pembelajaran yang berlangsung di semua obyek penelitian jika diamati mendalam semuanya sesuai dengan SOP Qiraati, bahkan bisa dikatakan kualitas pembelajaran mencerminkan kualitas guru dan jumlah santri yang ikut dalam TAS juga mencerminkan kualitas lembaga dalam pembelajaran. Dari pihak korcab menargetkan lulusan setiap periode TAS minimal $15 \%$ dari jumlah santri secara keseluruhan. Pembelajaran yang berlangsung selalau berbasis kompetensi siswa, artinya, setiap siswa mempunyai kesempatan untuk mempercepat proses belajar jika didukung oleh semua pihak dan kemampuan santri tersebut.untuk itu kemampuan santri difasilitasi betul oleh Qiraati untuk mencapai hal yang maksimal.

c. Evaluasi pembelajaran metode qiraati dalam pembelajaran di RA Kabupaten Cirebon

Pada ketiga lembaga tersebut memberikan penjelasan bahwa pembelajaran metode qiraati memiliki peluang yang besar bagi setiap peserta didik untuk dengan cepat menguasau membaca Al Quran. Sebuah metode yang membantu peserta didik dalam mempercepat penguasaan membaca Al Quran sebagaimana dalam diskusi penelitian ketika melakukan wawancara dengan seorang guru. Yang terlihat dalam dokumen wawancara berikut ini:

Evaluasi secara berkala dilakukan baik dari sisi pembelajaran maupun dari sisi kelembagaan, dan santri selalu dipacu untuk menyelesaikan programnya dengan cepat dan baik, hal itu tercermin dari kompetisi yang dibangun oleh lembaga dan reward yang selalu diberikan jika santri berprestasi.Evaluasi yang dilakukan juga selalu melalui siklus plan, do, control dan act. Hal ini terbukti dengan sistem evaluasi yang diberikan oleh guru, jika hasil akhir kenaikan jilid kurang sempurna maka dalam Qiraati biasa untuk mengembalikan kembali dalam 
pembelajaran, dan perlakuan ini sangat dipahami oleh semua santri dan wali santri sebagai sebuah kelaziman. Bahkan, evaluasi harian yang berupa ( $\mathrm{L}=$ Lulus) atau ( $\mathrm{L}-=$ mengulang) dalam buku prestasi mereka tidak menjadi beban santri dan wali santri untuk semangat dalam pembelajaran.

Sementara evaluasi kelembagaan sangat mungkin berbasis kinerja lembaga yang selalu dipantau dengan hasil prosentase lulusan TAS yang minimal harus mencapai $15 \%$ dari jumlah santri yang aktif. Hal itu pula dilakukan dengan monev buku, dimana santri yang aktif merupakan parameter yang digunakan.

\section{Tabel 1. Daftar Peringkat Lembaga Tes TK Qiraati Plus 2017} Sumber: Korcab Cirebon Tahun 2017

\begin{tabular}{|c|c|c|c|c|c|c|c|c|c|}
\hline \multirow{2}{*}{ 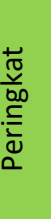 } & \multirow[b]{2}{*}{ Lembaga } & \multirow[b]{2}{*}{ Korcam } & \multicolumn{5}{|c|}{ Jumlah } & \multirow{2}{*}{$\begin{array}{l}\frac{\pi}{0} \\
\frac{1}{1} \\
\frac{\pi}{2} \\
\frac{\pi}{\bar{L}}\end{array}$} & \multirow{2}{*}{ 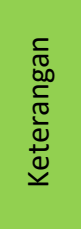 } \\
\hline & & & 竞 & 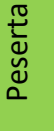 & 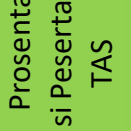 & $\frac{n}{3}$ & $\frac{\stackrel{2}{\frac{\pi}{O}}}{i=} \frac{n}{3}$ & & \\
\hline 1 & Hidayatushibyan (K) & Kejaksan & 53 & 17 & $32,08 \%$ & 17 & 0 & 8,42 & $100 \%$ \\
\hline 2 & Hidayatushibyan $(\mathrm{H})$ & Harjamukti & 50 & 12 & $24,00 \%$ & 12 & 0 & 8,41 & $100 \%$ \\
\hline 3 & Al Muttaqin & Tengah Tani & 58 & 23 & $39,66 \%$ & 23 & 0 & 8,29 & $100 \%$ \\
\hline 4 & Ta'alumil Quran & Kejaksaan & 54 & 20 & $37,04 \%$ & 20 & 0 & 8,28 & $100 \%$ \\
\hline 5 & Nurul Huda & Tengah Tani & 109 & 35 & $32,11 \%$ & 35 & 0 & 8,20 & $100 \%$ \\
\hline 6 & Shidqul Amal & Tengah Tani & 74 & 19 & $25,68 \%$ & 19 & 0 & 8,08 & $100 \%$ \\
\hline
\end{tabular}

\section{KESIMPULAN}

a) Perencanaan dalam pembelajaran Al-Qur'an di RA diwujudkan dengan menyiapkan SDM Guru yang bersyahadah, kegiatan KBM yang berstandar Qiraati dan membangun lembaga RA yang kokoh dalam kelembagaannya.

b) Pelaksanaan kegiatan belajar mengajar Al-Qur'an di RA diwujudkan dengan pembelajaran yang sesuai standar qiraati, pembinaan Guru melalui MMQ, hubungan kordinasi antar lembaga, korcam, dan korcab hingga korpus dalam pembelajaran.

c) Evaluasi pembelajaran Al-Qur'an di RA dengan mengadakan kegiatan tes akhir santri, terbukti banyaknya santri yang mengikutinya dari sejumlah 27 lembaga diikuti peserta 390 orang dari jumlah santri seluruh lembaga berjumlah 1426 orang, hasil tersebut baru mencapai prosentase $27,35 \%$ di tahun 2017. 


\section{DAFTAR PUSTAKA}

Akdon. (2008). Aplikasi Statistika dan Metode Penelitian untuk Administrasi dan Manajemen. Bandung: Dewa Ruchi.

Anderson W, Lorin, dan Krathwol R, David. (2010). Kerangka Landasan Pembelajaran, Pengajaran dan Asesmen. Yoyakarat: Pustaka Pelajar.

Arifin, Zaenal. (2013). Evaluasi Pembelajaran. Prinsip Teknik prosedur. Bandung: PT Remaja Rosdakarya.

Arikunto, Suharsimi. (2002). Prosedur Penelitian Suatu Pendekatan Praktek. Edisi Revisi. Jakarta: Rineke Cipta.

Asmawati, Luluk. (2014). Perencanaan Pembelajaran PAUD. Bandung: PT Remaja Rosdakarya.

Aunurrahman. (2012). Belajar dan Pembelajaran. Bandung: Penerbit Alfabeta.

Chairunnisa, Connie. (2016). Manajemen Pendidikan dalam Multir Perspektif. Jakarta: Rajawalo Pers.

Chatib, Munif. (2016). Sekolahnya Manusia. Sekolah Berbasis Multiple Intelegences di Indonesia. Bandung: Kaifa.

Dryden, Gordon dan Vos, Jeannette. (2000). Revolusi cara Belajar The Learning Revolution. Belajar akan Efektif kalau dalam keadaan "Fun" Keajaiban Pikiran. Bandung: kaifa.

Fadlillaah, DKK. (2014). Edutainment Pendidikan Anak Usia Dini. Menciptakan Pembelajaran Menarik, Kreatif dan Menyenangkan. Jakarta: Kencana.

Hoy, K Wayne dan Miskel, G Cecil. (2008). Educational Administration Theory, Research, and practice (Eighth Edition). New York: McGraw-Hill Company.

Huda, Miftahul. (2015). Model-model Pengajaran dan Pembelajaran Isu-isu Metodis dan Paradigmatis. Yogyakarta: Pustaka Pelajar.

Isjoni. (2007). Integrated Learning. Pekanbaru: Falah Prodution.

Kemendikbud. (2013). Materi Pelatihan Guru Implementasi Kurikulum 2013. Jakarta: BPSDMPKPMP Kemendikbud.

Komariah, Aan dan Triatna, Cepi. (2010). Visionary Leadership Menuju Sekolah Efektif. Jakarta: Bumi Aksara.

Kunandar. (2014). Penilaian Autentik. Penilaian Hasil Belajar Peserta Didik Berdasarkan Kurikulum 2013. Suatu Pendekatan Praktis. Jakarta: Rajawali Pers.

Majid, Abdul. (2014). Pembelajaran Tematik Terpadu. Bandung: PT Remaja Rosdakarya.

Masri, Singarinbum dan Effendi. (2003). Metode Penelitian Survei. (Jakarta: LP3ES).

Montessori, Maria. (2015). Metode Montessori. Panduang Wajib untuk Guru dan Orang Tua Didik PAUD (Pendidikan Anak Usia dini). Penerjemah Ahmad Lintang Lazuardi. Yogyakarta: Pustaka pelajar.

Mosnan, M. (2014). Pendekatan Saintifik dan Kontekstual dalam Pembelajaran Abad 21. Jakarta: Ghalia Indonesia.

Mulyasa, E. (2014). Pengembangan dan Impelementasi Kurikulum 2013. Bandung: PT Remaja Rosdakarya.

Mursid. (2015). Belajar dan Pembelajaran PAUD. Bandung: PT Remaja Rosdakarya.

Musbikin, Imam. (2010). Buku Pintar PAUD, Tuntunan dalam Perspektif para Guru PAUD. Dalam Perspektif Islami. Yogyakarta: Laksana.

Nazir, Moh. (2011). Metode Penelitian. Jakarta: Ghalia Indonesia. 
Riduwan. (2010). Metode dan Teknik Menyusun Proposal Penelitian. Bandung: Alfabeta.

Sani A, Ridwan. (2014). Pembelajaran Saintifik untuk Implementasi Kurikulum 2013. Jakarta: Bumi Aksara.

Sanjaya, Wina. (2013). Kurikulum dan Pembelajaran Teori dan Praktik Pengembangan KTSP. Jakarta: Kencana.

Sanusi, Achmad. (2017). Manajemen Pendidikan Mengurai benang Kusut, Mencari Jalan Keluar. Bandung:Nuansa

Sugioyono. (2016). Metode Penelitian Pendidikan Pendekatan Kuantitatif, Kualitatif, dan $R$ \& $D$. Bandung: Alfabeta.

Supiana. (2009). Metodologi Studi Islam. Direktorat Jenderal Pendidikan Islam Kementerian Agama RI.Seri Modul Dual Mode System. Jakarta: Dirjen Pendis Kemenag RI.

Syah, Muhibbin. (2013). Psikologi Belajar. Pengantar Prof. Dr. S.C. Utami Munandar. Jakarta: Rajawali Pers.

Usman, Husaini. (2009). Manajemen, Teori, Praktek dan Riset Pendidikan. Jakarta: Bumi Aksara

Zubaedi. (2017). Strategi Taktis Pendidikan Karakter (untuk PAUD dan Sekolah). Jakarta: Rajawali Pers. 